\title{
KAJIAN MY MACHINE PROGRAM PADA PROSES PRODUKSI KACA LEMBARAN DI PT X
}

\author{
Sumanto \\ Program Studi Teknik Industri, \\ Universitas Bhayangkara Jaya, \\ Jl. Raya Perjuangan,Bekasi Utara,Bekasi Jawa Barat. \\ e-mail : sumanto_061961@yahoo.com
}

\begin{abstract}
A b strak
Persaingan dunia usaha saat ini semakin kompetitif. Semua perusahaan, khususnya bidang manufaktur, berusaha untuk memberikan yang terbaik bagi konsumennya dengan produk yang berkualitas yang baik serta harga yang terjangkau. Oleh karena itu, setiap perusahaan manufaktur harus pintar menyiasati dan menerapkan strategi yang tepat dalam mendukung proses produksinya. Di sini akan dibahas mengenai strategi My Machine Program yang secara signifikan bisa membuat proses produksi menjadi lebih baik dalam hal peralatan. Penerapan yang benar dari strategi My Machine Program ini dapat meningkatkan kestabilan operasi peralatan proses produksi sehingga kelangsungan hidup sebuah perusahaan manufaktur dapat terus terjaga. Analisa untuk mencari akar penyebab masalah yaitu dengan WWA (Why Why Analisis ). Sampel yang digunakan adalah dengan mengunakan data sekunder, yaitu data dari bagian maintenance yang meliputi jumlah kerusakan dalam setiap tahunnya dan waktu terbuang (losses) akibat kerusakan peralatan atau breakdown trouble. Pengujian ini membandingkan kinerja peralatan produksi 5 tahun sebelum penerapan My Machine Program dan 3 tahun sesudah penerapan My Machine Program.

Setelah diterapkan strategi My Machine Program, maka hasil analisis menggunakan why why Analysis menunjukkan bahwa setelah penerapan strategi My Machine Program, kinerja peralatan produksi yang meliputi efektifitas peralatan, biaya, tenaga kerja dan tingkat cacat produksi secara signifikan lebih baik dibandingkan sebelum penerapan strategi My Machine Program dengan derajat keberartian sebesar $95 \%$. Perbaikan dari kinerja peralatan produksi setelah penerapan strategi My Machine Program akan membantu kinerja perusahaan manufaktur secara menyeluruh.
\end{abstract}

Kata kunci : My Machine Program, peralatan, , tenaga kerja, tingkat kestabilan operational peralatan.

\section{PENDAHULUAN}

Peningkatan kinerja dalam perspektif finansial maupun non finansial merupakan tujuan utama dari aktivitas bisnis industri. Industri manufakture merupakan salah satu industri yang harus meningkatkan kinerjanya terus menerus untuk dapat meningkatkan keuntungan dan daya saing akibat ketatnya persaingan.

Salah satu industri manufaktur Indonesia yang harus dapat memenangkan persaingan pada tingkat dunia adalah industri kaca lembaran. Proses produksi kaca lembaran dengan dua tungku yaitu tungku 1 dan tungku 2 dengan total kapasitas 1000 ton /hari, didukung oleh peralatan mekanik maupun listrik yang sangat bervariasi model dan tahun pembuatan. Proses produksi kaca lembaran bersifat terus menerus dalam dua puluh empat jam selama 15 tahun ,sehingga memerlukan peralatan yang handal. Untuk itu diperlukan pemeliharaan yang sistematis. Kondisi ini menjadi dasar dalam penelitian ini yaitu metode pemeliharaan yang tepat dan memadai untuk meningkatkan kinerja dari peralatan tersebut. 
Pada lima tahun terakhir yaitu mulai tahun 2006 sampai dengan 2010, proses produksi kaca lembaran pada perusahaan ini menunjukkan penurunan hasil yang diakibatkan oleh gangguan peralatan seperti ditunjukkan pada grafik 1 dan 2.

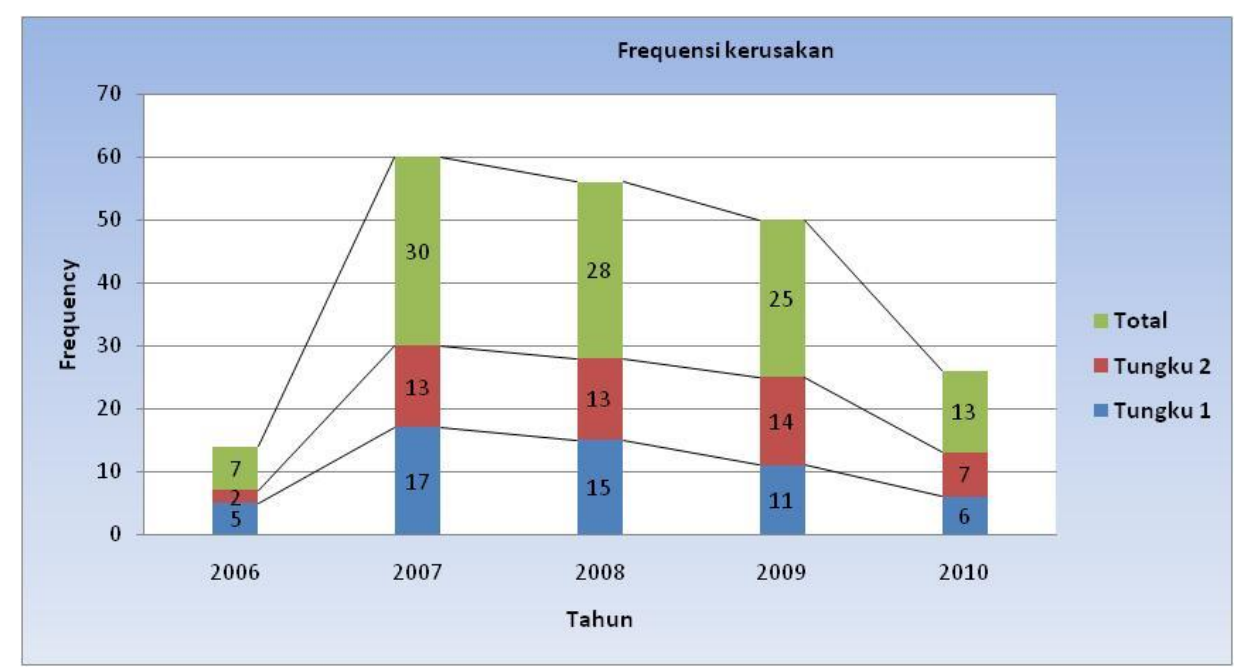

Gambar 1 Grafik Frekuensi kerusakan

Sumber : summary trouble report maintenance (2011)

Dari grafik 1 terlihat bahwa mulai dari tahun 2007 sampai dengan 2010 terjadi penurunan jumlah kerusakan dari 30 kali menjadi 13 kali. Sedangkan disisi lain untuk losses menunjukan kenaikan yang sangat signifikan, untuk data losses dapat dilihat pada grafik di bawah :

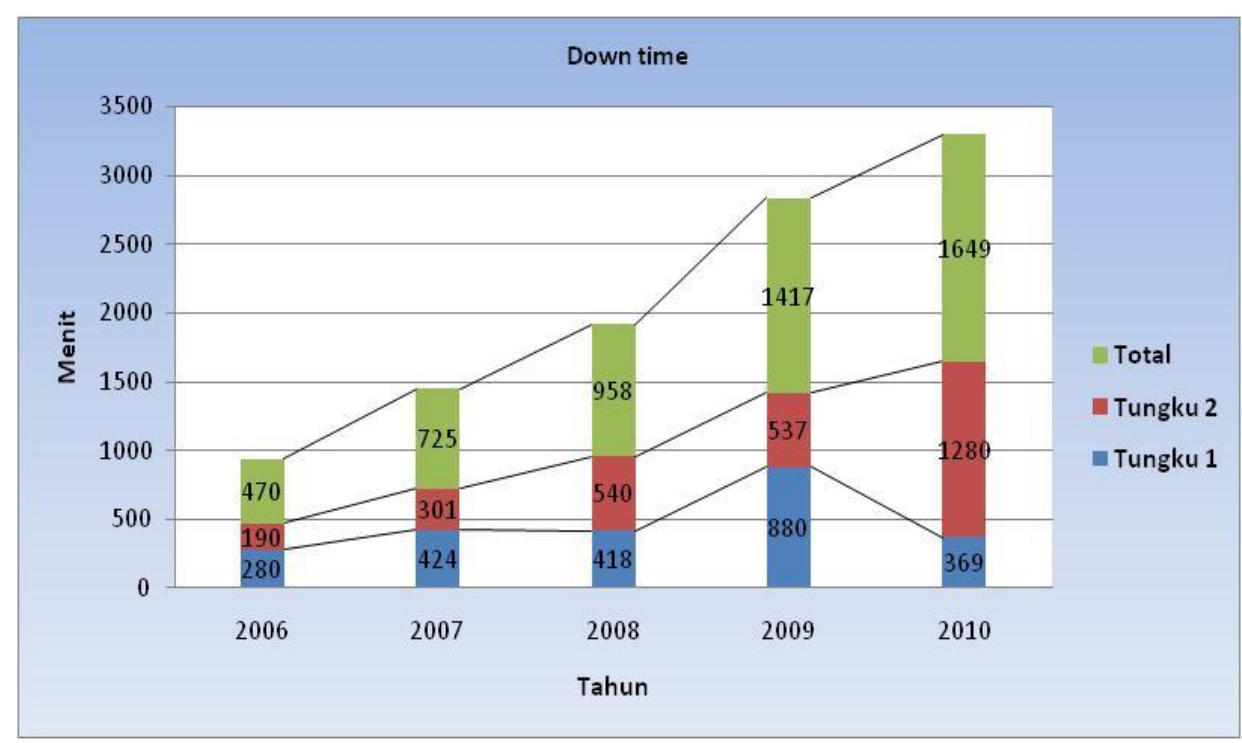

Gambar 2 Grafik Waktu produksi hilang atau losses

Sumber : summary trouble report Maintenance (2011).

Grafik diatas menunjukan bahwa dari tahun 2006 sampai dengan 2010 untuk total losses semakin besar. Grafik 1 dan 2 menunjukkan bahwa dari tahun ke tahun semakin besar jumlah waktu hilang dan untuk tahun 2010 walaupun frekuensi kerusakan menurun tetapi waktu yang hilang atau down time atau losses cukup besar. 
Berdasarkan hal tersebut di atas maka peneliti sebagai anggota dari Divisi Maintenance and Power juga mempunya KPI, ada 6 indiator yang harus dikontrol ,dari keenam Indicator tersebut salah satunya adalah "Excelent Operation " atau kestabilan operasional peralatan,dalam hal ini yang dikontrol adalah Kerusakan Peralatan ,karena pada tahun 2010 cukup mengganggu kesetabilan operasi mesin sehingga KPI divisi Maintenance tidak tercapai.

Melakukan penelitian yaitu dengan mengkaji sistem pemeliharaan mesin produksi pada proses peleburan bahan baku, penelitian tentang kinerja dari sistem pemeliharaan peralatan.Sistem pemeliharaan yang dilakukan pada obyek penelitian adalah pelaksanaa My Machine Program dari tahun 2011.

My Machine Program adalah nama program atau sistem pemeliharaan peralatan yang dibuat oleh team yang terdiri dari orang orang yang berkonsentrasi pada pemeliharaan peralatan yaitu dari Divisi Maintenance dan Divisi Produksi PT. X untuk melakukan pemeliharaan secara mandiri yang dilakukan oleh operator dengan porsi yang telah ditentukan. sistim pemeliharaan ini konsepnya sama dengan metode Total Productive Maintenance (TPM).

\section{METODE PENELITIAN}

Dalam penelitian ini melalui beberapa tahapan ,seperti ditunjukkan oleh flow chart sbb:

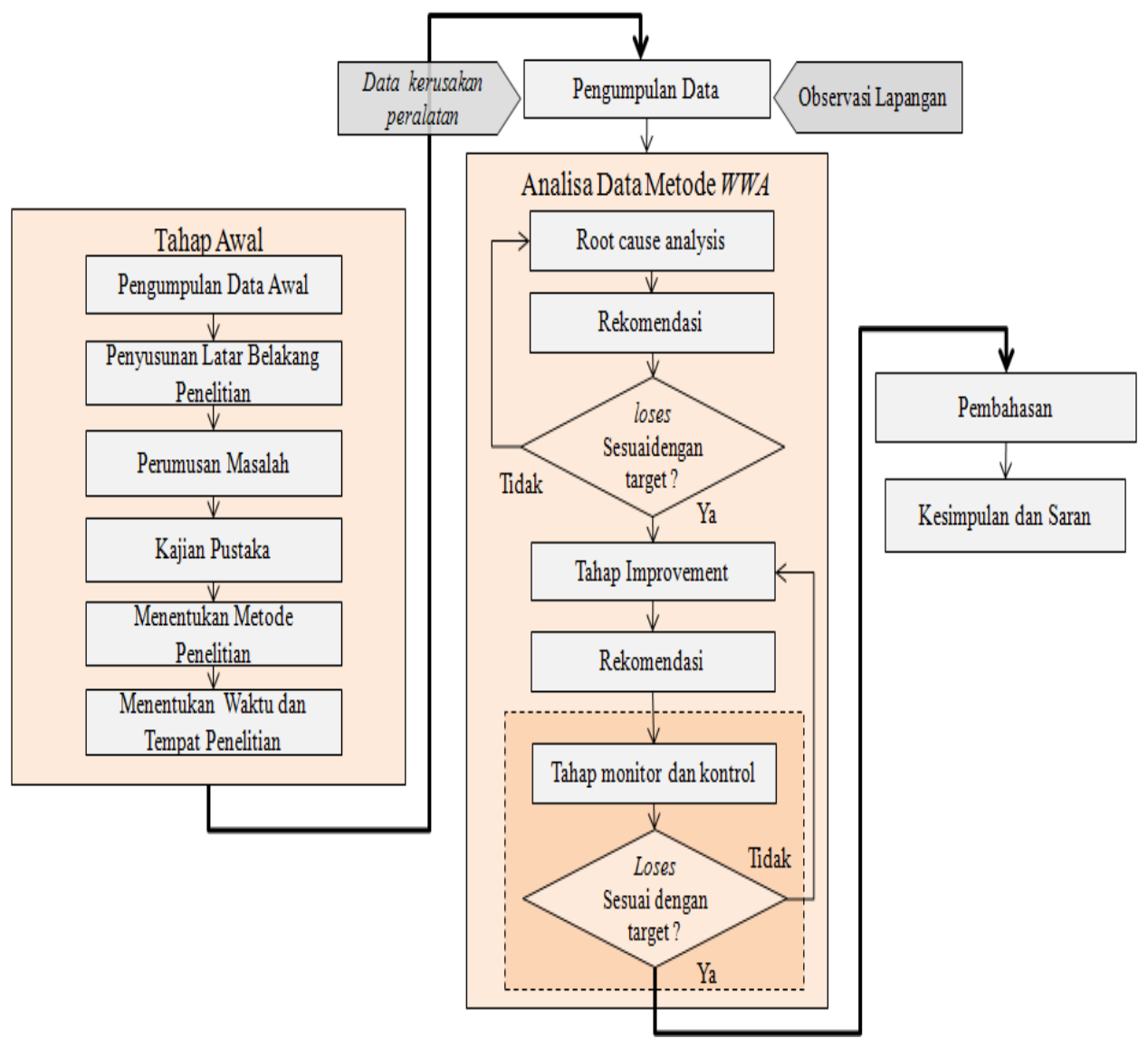

Gambar 3 Tahapan penelitian 


\section{HASIL DAN PEMBAHASAN}

\section{Data kerusakan peralatan 2010}

Dibawah ini adalah data frekuensi kerusakan, waktu produksi yang hilang atau losses dan target KPI pada tahun 2010.

Tabel 1. Data losses tahun 2010

\begin{tabular}{|c|c|c|c|c|c|c|c|c|c|c|c|c|c|c|}
\hline \multirow{2}{*}{ No. } & \multirow{2}{*}{ CAT } & \multicolumn{13}{|c|}{2010} \\
\hline & & JAN & FEB & MAR & APR & MAY & JUN & JUL & AUG & SEP & OCT & NOV & DEC & TOTAL \\
\hline \multirow{5}{*}{ TUNGKU } & $S$ & 1 & 0 & 0 & 0 & 0 & 0 & 2 & 0 & 0 & 0 & 0 & 0 & 3 \\
\hline & A & 0 & 0 & 0 & 0 & o) & 0 & 0 & 1 & 0 & 0 & 0 & 0 & 1 \\
\hline & $B$ & 0 & 0 & 0 & 1 & 0 & 0] & 0 & 0 & 1 & 0 & 0 & 0 & 2 \\
\hline & TOTAL & 1 & 0 & 0 & 1 & 0 & 0 & 2 & 1 & 1 & 0 & 0 & 0 & 6 \\
\hline & Loss(min) & 35 & & & & & & 305 & 29 & & & & & 369 \\
\hline \multirow{5}{*}{ TUNGKU } & $S$ & 1 & 0 & 0 & 0 & 0 & 0 & 0 & 1 & 0 & 0 & 1 & 0 & 3 \\
\hline & A & 0 & 0 & of & 0 & 0 & 0 & 0 & 1 & 0 & 0 & 의 & 0 & 1 \\
\hline & B & 0 & 1 & 0 & 0 & 0 & 1 & 1 & 0 & 0 & 0 & of & 0 & 3 \\
\hline & TOTAL & 1 & 1 & 0 & 0 & 0 & 1 & 1 & 2 & 0 & 0 & 1 & 0 & 7 \\
\hline & Loss(min) & 290 & 20 & & & & & & 895 & & & 75 & & 1280 \\
\hline \multicolumn{2}{|c|}{ TOTAL FREQ. } & 2 & 1 & 0 & 1 & 0 & 1 & 3 & 3 & 1. & 0 & 1 & 0 & 13 \\
\hline \multicolumn{2}{|c|}{ TOTAL LOSS TIME } & 325 & 20 & 0 & 0 & 0 & 0 & 305 & 924 & 0 & 0 & 75 & 0 & 1.649 \\
\hline \multicolumn{2}{|c|}{ TARGET FREQ. } & 1 & 0 & 2 & 0 & 1 & 3 & 3 & 2 & 0 & 1 & 0 & 5 & \\
\hline \multicolumn{2}{|c|}{ AAC TRGT FREQ. } & 1 & 1 & 3 & 3 & 4 & 7 & 10 & 12 & 12 & 13 & 13 & 18 & 18 \\
\hline \multicolumn{2}{|c|}{ TARGET $\mathrm{L} T(\mathrm{MNT})$} & 73 & 73 & 73 & 73 & 73 & 73 & 73 & 73 & 73 & 73 & 73 & 73 & \\
\hline \multicolumn{2}{|c|}{ ACC TARGET L/T (MNT) } & 73. & 145 & 218 & 290 & 363 & 435 & 508 & 580 & 653 & 725 & 798 & 870 & 870 \\
\hline
\end{tabular}

\section{Evaluasi hasil KPI Devisi Maintenance tahun 2010}

Data kerusakan di atas menunjukkan bahwa untuk kehilangan waktu produksi masih belum mencapai target,dapat disimpulkan seperti berikut ini.

Tabel 2. Pencapaian KPI tahun 2010

\begin{tabular}{|l|c|c|c|c|}
\hline & Target KPI & Pencapaian & Hasil & Catatan \\
\hline Frekuensi (kali) & 18 & 13 & $-28 \%$ & Tercapai \\
\hline Losses (mnt) & 870 & $\mathbf{1 6 4 9}$ & $+190 \%$ & Tidak tercapai \\
\hline
\end{tabular}

\section{Menentukan target KPI Tahun 2011.}

Dari hasil pencapaian tahun 2010 diatas menunjukkan bahwa perlu dilakukan strategi lain untuk dapat mencapai target yang telah ditentukan, sehingga ditentukan target KPI tahun 2011 sbb:

Tabel 3. Prosentase Pencapaian KPI tahun 2010

\begin{tabular}{|l|c|c|c|}
\hline & Pencapaian 2010 & Pencapaian & Turun \\
\hline Frekuensi (kali) & 13 & 9 & $-30 \%$ \\
\hline Losses (mnt) & $\mathbf{1 6 4 9}$ & $\mathbf{4 2 9}$ & $-74 \%$ \\
\hline
\end{tabular}


Dibawah ini adalah data kerusakan peralatan tahun 2011.

Tabel 4.Frequensi kerusakan tahun 2011

\begin{tabular}{|c|c|c|c|c|c|c|c|c|c|c|c|c|c|c|c|}
\hline \multirow{2}{*}{ NO. } & \multirow{2}{*}{ CAT. } & \multicolumn{14}{|c|}{2011} \\
\hline & & 2010 & JAN & FEB & MAR & APR & MAY & JUN & JUL & AUG & SEP & OCT & NOV & DEC & TOTAL \\
\hline \multirow{5}{*}{$\begin{array}{c}\text { TUNGKU } \\
\text { NO. } 2\end{array}$} & $S$ & & 1 & 1 & 1 & 0 & 0 & 0 & 0 & 0 & 0 & 0 & 0 & 0 & 3 \\
\hline & A & & 0 & 0 & 0 & 0 & 0 & 0 & 0 & 0 & 0 & 0 & 0 & 0 & 0 \\
\hline & $B$ & & 0 & 0 & 0 & 0 & 0 & 1 & 0 & 0 & 0 & 0 & 0 & 0 & 1 \\
\hline & $A+B$ & & 0 & 0 & 0 & 0 & 0 & 1 & 0 & 0 & 0 & 0 & 0 & 0 & 1 \\
\hline & TOTAL & 6 & 1 & 1 & 1 & 0 & 0 & 1 & 0 & 0 & 0 & 0 & 0 & 0 & 4 \\
\hline \multicolumn{3}{|c|}{ TOTAL ACC } & 1,0 & 2,0 & 3,0 & 3,0 & 3,0 & 4,0 & 4,0 & 4,0 & 4,0 & 4,0 & 4,0 & 4,0 & \\
\hline \multirow{8}{*}{$\begin{array}{l}\text { TUNGKU } \\
\text { NO.1 }\end{array}$} & $S$ & & 0 & 0 & 0 & 0 & 0 & 0 & 0 & 0 & 0 & 0 & 0 & 0 & 0 \\
\hline & A & & 0 & 0 & 1 & 0 & 0 & 0 & 0 & 0 & 0 & 0 & 0 & 0 & 1 \\
\hline & $B$ & & 0 & 0 & 0 & 0 & 0 & 0 & 0 & 0 & 2 & 0 & 0 & 0 & 2 \\
\hline & $A+B$ & & 0 & 0 & 1 & 0 & 0 & 0 & 0 & 0 & 2 & 0 & 0 & 0 & 3 \\
\hline & TOTAL & 7 & 0 & 0 & 1 & 0 & 0 & 0 & 0 & 0 & 2 & 0 & 0 & 0 & 3 \\
\hline & TOTAL A & $A C C$ & 0,0 & 0,0 & 1,0 & 1,0 & 1,0 & 1,0 & 1,0 & 1,0 & 3,0 & 3,0 & 3,0 & 3,0 & \\
\hline & TARGET & & 0,8 & 0,8 & 0,8 & 0,8 & 0,8 & 0,8 & 0,8 & 0,8 & 0,8 & 0,8 & 0,8 & 0,8 & 9 \\
\hline & ACC TAF & RGET & 0,8 & 1,5 & 2,3 & 3,0 & 3,8 & 4,5 & 5,3 & 6,0 & 6,8 & 7,5 & 8,3 & 9,0 & \\
\hline
\end{tabular}

Dibawah ini adalah waktu produksi yang hilang atau losses tahun 2011

Tabel 5.Waktu produksi hilang tahun 2011

\begin{tabular}{|c|c|c|c|c|c|c|c|c|c|c|c|c|c|c|c|}
\hline \multirow{2}{*}{ NO. } & \multirow{2}{*}{ CAT } & \multirow{2}{*}{2010} & \multicolumn{13}{|c|}{2011} \\
\hline & & & JAN & FEB & MAR & APR & MAY & JUN & JUL & AUG & SEP & ОСТ & NOV & $\mathrm{DEC}$ & TOTAL \\
\hline \multirow{5}{*}{$\begin{array}{c}\text { TUNGKU } \\
\text { N0.2 }\end{array}$} & $S$ & & 50 & 149 & 40 & 0 & 0 & 0 & 0 & 0 & 0 & 0 & 0 & 0 & 239 \\
\hline & A & & 0 & 0 & 0 & 0 & 0 & 0 & 0 & 0 & 0 & 0 & 0 & 0 & 0 \\
\hline & $B$ & & 0 & 0 & 0 & 0 & 0 & 0 & 0 & 0 & 0 & 0 & 0 & 0 & 0 \\
\hline & $A+B$ & & 0 & 0 & 0 & 0 & 0 & 0 & 0 & 0 & 0 & 0 & 0 & of & 0 \\
\hline & TOTAL & 369 & 50 & 149 & 40 & 0 & 0 & 0 & 0 & 0 & 0 & 0 & 0 & & 239 \\
\hline \multirow{5}{*}{$\begin{array}{c}\text { TUNGKU } \\
\text { N0.1 }\end{array}$} & $S$ & & 0 & 0 & 0 & 0 & 0 & 0 & 0 & 0 & 0 & 0 & 0 & 0 & 0 \\
\hline & A & & 0 & 0 & 20 & 0 & 0 & 0 & 0 & 0 & 0 & 0 & 0 & 0 & 20 \\
\hline & B & & 0 & 0 & 0 & 0 & 0 & 0 & 0 & 0 & 0 & 0 & 0 & 0 & 0 \\
\hline & $A+B$ & & 0 & 0 & 20 & 0 & 0 & 0 & 0 & 0 & 0 & 0 & 0 & 0 & 20 \\
\hline & TOTAL & 1280 & 0 & 0 & 20 & 0 & 0 & 0 & 0 & 0 & 0 & 0 & 0 & & 20 \\
\hline TOTAL & & 1649 & 50 & 149 & 60 & 0 & 0 & 0 & 0 & 0 & 0 & 0 & 0 & 0 & 259 \\
\hline \multicolumn{2}{|c|}{ ACCUMULATION } & & 50 & 199 & 259 & 259 & 259 & 259 & 259 & 259 & 259 & 259 & 259 & 259 & \\
\hline \multicolumn{2}{|l|}{ TARGET } & & 36 & 36 & 36 & 36 & 36 & 36 & 36 & 36 & 36 & 36 & 36 & 36 & \\
\hline \multicolumn{2}{|c|}{ TARGET ACC } & & 36 & 72 & 107 & 143 & 179 & 215 & 250 & 286 & 322 & 358 & 393 & 429 & \\
\hline
\end{tabular}

\section{Evaluasi hasil KPI Devisi Maintenance tahun 2011}

Data kerusakan di atas menunjukkan bahwa frequensi kerusakan dan kehilangan waktu produksi atau losses mencapai target,dapat disimpulkan seperti berikut ini.

Tabel 6. Pencapaian KPI tahun 2011

\begin{tabular}{|l|c|c|c|c|}
\hline & Target 2011 & Pencapaian & Hasil & Catatan \\
\hline Frekuensi (kali) & 9 & 7 & $-22 \%$ & Tercapai \\
\hline Losses (mnt) & 429 & 259 & $-40 \%$ & Tercapai \\
\hline
\end{tabular}




\section{Menentukan target KPI Tahun 2012.}

Dari hasil pencapaian tahun 2011 diatas menunjukkan bahwa perlu dilakukan strategi lain untuk dapat mencapai target yang telah ditentukan, sehingga ditentukan target KPI tahun 2012 sbb:

Tabel 7. Prosentase Pencapaian KPI tahun 2011

\begin{tabular}{|l|c|c|c|}
\hline & Pencapaian 2011 & Target 2012 & Turun \\
\hline Frekuensi (kali) & 7 & 3 & $57.1 \%$ \\
\hline Losses (mnt) & $\mathbf{2 5 9}$ & $\mathbf{1 0 4}$ & $60 \%$ \\
\hline
\end{tabular}

Dibawah ini adalah data kerusakan peralatan tahun 2012

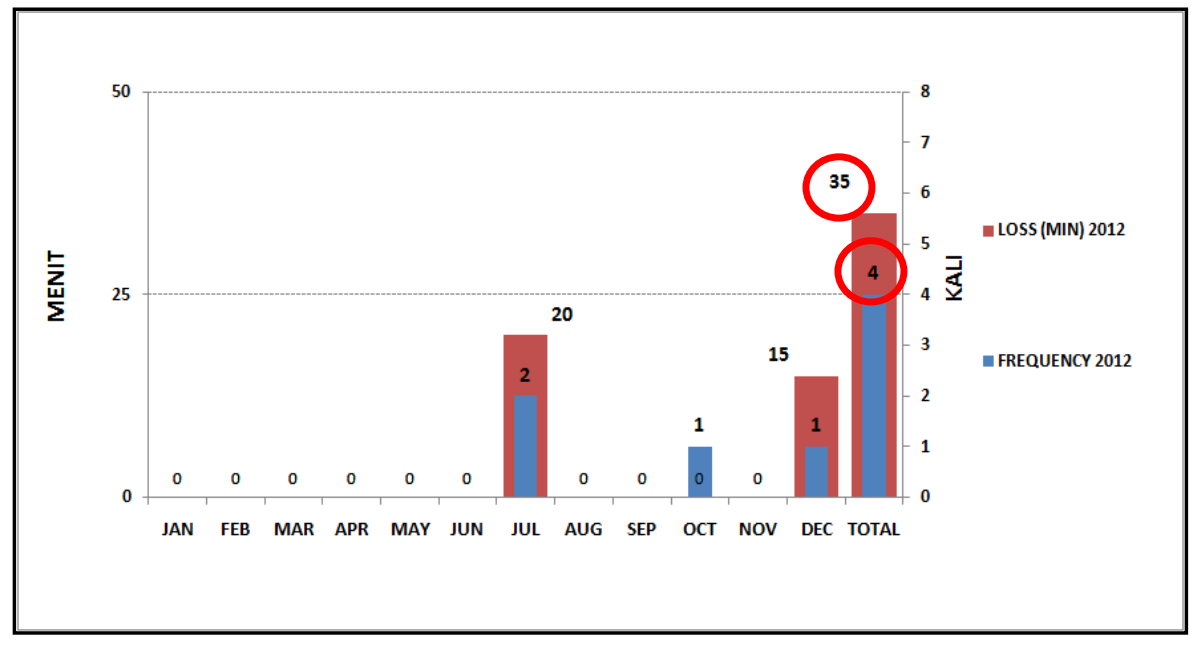

Gambar 4 Grafik Kerusakan peralatan 2012

Sumber : summary trouble report Maintenance (2012).

\section{Evaluasi hasil KPI Devisi Maintenance tahun 2012}

Data kerusakan di atas menunjukkan bahwa frequensi kerusakan dan kehilangan waktu produksi atau losses mencapai target,dapat disimpulkan seperti berikut ini:

Tabel 8. Pencapaian KPI tahun 2012

\begin{tabular}{|l|c|c|c|c|}
\hline & Target 2012 & Pencapaian & Hasil & Catatan \\
\hline Frekuensi (kali) & 3 & 4 & $+33.3 \%$ & Tidak tercapai \\
\hline Losses (mnt) & $\mathbf{1 0 4}$ & $\mathbf{3 5}$ & $-60 \%$ & Tercapai \\
\hline
\end{tabular}




\section{Menentukan target KPI Tahun 2013.}

Dari hasil pencapaian tahun 2012 diatas menunjukkan bahwa untuk frequensi kerusakan tidak mencapai target sehingga perlu dilakukan strategi lain untuk dapat mencapai target yang telah ditentukan, sehingga ditentukan target KPI tahun 2013 sbb:

Tabel 9. Perbandingan Pencapaian KPI tahun 2012 vs 2013

\begin{tabular}{|l|c|c|c|}
\hline & Pencapaian 2012 & Target 2013 & Turun \\
\hline Frekuensi (kali) & 4 & 1 & $-75 \%$ \\
\hline Losses (mnt) & $\mathbf{3 5}$ & $\mathbf{3 0}$ & $14.2 \%$ \\
\hline
\end{tabular}

Dibawah ini adalah data kerusakan peralatan tahun 2013

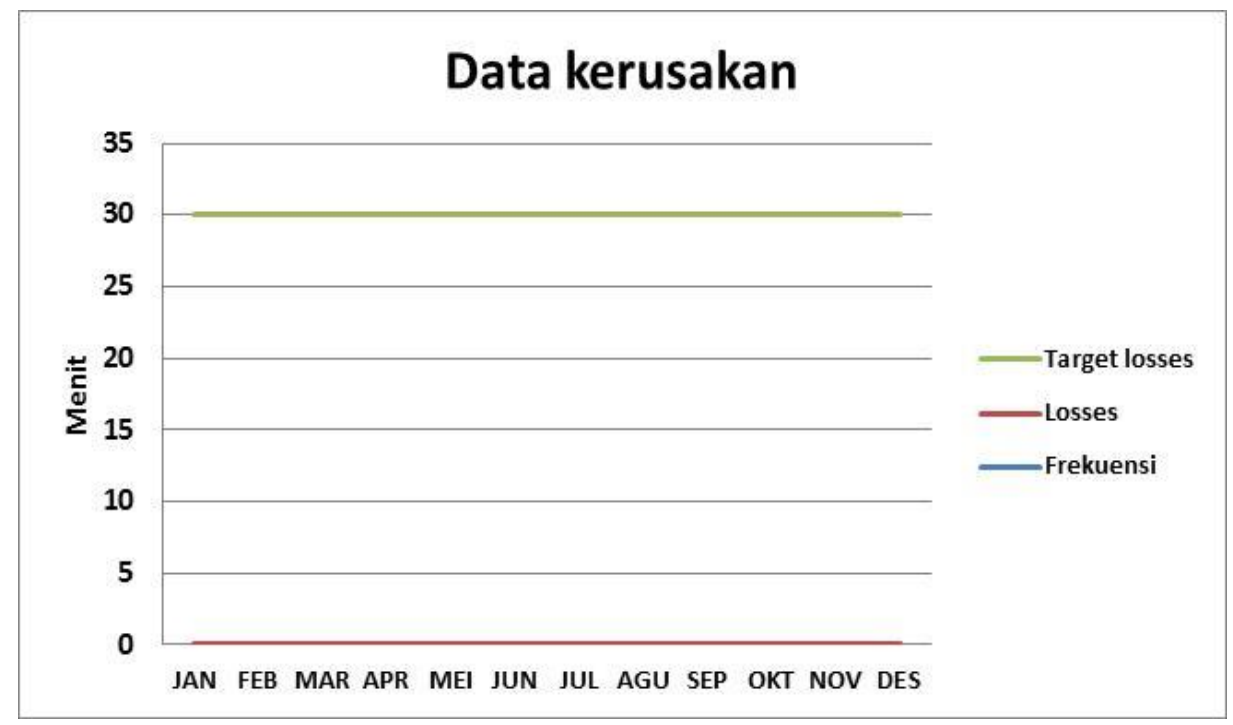

Gambar 5 Grafik Kerusakan peralatan 2012

Sumber : summary trouble report Maintenance (2012).

\section{Evaluasi hasil KPI Devisi Maintenance tahun 2013}

Data kerusakan di atas menunjukkan bahwa frequensi kerusakan dan kehilangan waktu produksi atau losses mencapai target,dapat disimpulkan seperti berikut ini:

Tabel 10. Pencapaian KPI tahun 2013

\begin{tabular}{|l|c|c|c|c|}
\hline & Target 2013 & Pencapaian & Hasil & Catatan \\
\hline Frekuensi (kali) & 1 & 0 & $100 \%$ & Tercapai \\
\hline Losses (mnt) & $\mathbf{3 0}$ & $\mathbf{0}$ & $100 \%$ & Tercapai \\
\hline
\end{tabular}




\section{Diskusi}

\section{Temuan utama}

Dari hasil penelitian yang telah dilakukan dan telah dianalisa, secara umum dapat disimpulkan bahwa terjadi perubahan yang signifikan dari kinerja - kinerja produksi sebelum diterapkan strategi My Machine Program dengan sesudah diterapkan strategi My Machine Program.

Dalam jangka waktu 2 tahun sejak diterapkan My Machine Program, kinerja - kinerja peralatan produksi dan sumber daya manusia dapat menjadi lebih baik. Hal ini ditunjukkan dengan beberapa temuan antara lain :

\section{Temuan Key Performance Indicator tidak mencapai target :}

1. Terjadi peningkatan jumlah losses waktu produksi yang diakibatkan oleh kerusakan mesin pada dekade empat tahun dari tahun 2006 sampai dengan tahun 2010.

2. Key Performance Indicator untuk tahun 2010 tidak tercapai

Analisa penyebab utama (Root cause analysis )

Dari catatan diatas bahwa target KPI tahun 2010 untuk losses tidak tercapai,sehingga peneliti melakukan analisa untuk mendapatkan penyebab utama. Dalam tahapan analisa ini peneliti membuat tujuh kategori penyebab kerusakan.

Kategori penyebab kerusakan tersebut dijelaskan sebagai berikut :

1. Maintenance Quality (Kualitas Maintenance ):

- Kerusakan yang diakibatkan oleh kurangnya ketelitian saat melakukan regular maintenance ( pemeliharaan berkala )

- Menunda jadual pelaksanaan regular maintenance.

2. Daily care ( keperdulian ): Mis operation, melakukan kesalahan operasi mesin ,misalnya tiba tiba tidak sengaja menekan push button emergency dan tidak melaporkan saat menemukan kelainan pada peralatan.

3. Construction (Konstruksi): Terjadi ketidak sesuaian saat pemasangan pertama, misalnya, Posisi pipa pendingin masuk dan keluar terbalik dan bisa juga terjadi kesalahan penyambungan kabel.

4. Design work (Pekerjaan perancangan) : Design tidak sesuai dengan spesifikasi dasar atau basic spesifikasi.Misalnya : Pemasangan komponen yang qualitas atau kapasitaslebih rendah dari spesifikasi .

5. Life time (Umur peralatan ):

Umur peralatan yang sudah melebihi spesifikasi yang ditentukan oleh pembuatnya,dan ini sangat tergantung dengan kondisi lingkungannya.

6. Kebersihan, Soft bug and not clear (Sesuatu yg belum jelas ):

Trouble yang belum jelas penyebabya, ini terjadi kalau masalahnya kadang ada kadang bagus dengan sendirinya.

7. Force major

Kerusakan yang diakibatkan oleh karena terjadinya gempa bumi atau bencana lainnya yang tidak diduga.

Metode analisa yang yang digunakan adalah dengan WWA (Why Why Analysis ),dari hasil analisa tersebut maka dibuatkan grafik pareto untuk dapat menentukan prioritas pemecahannya. 


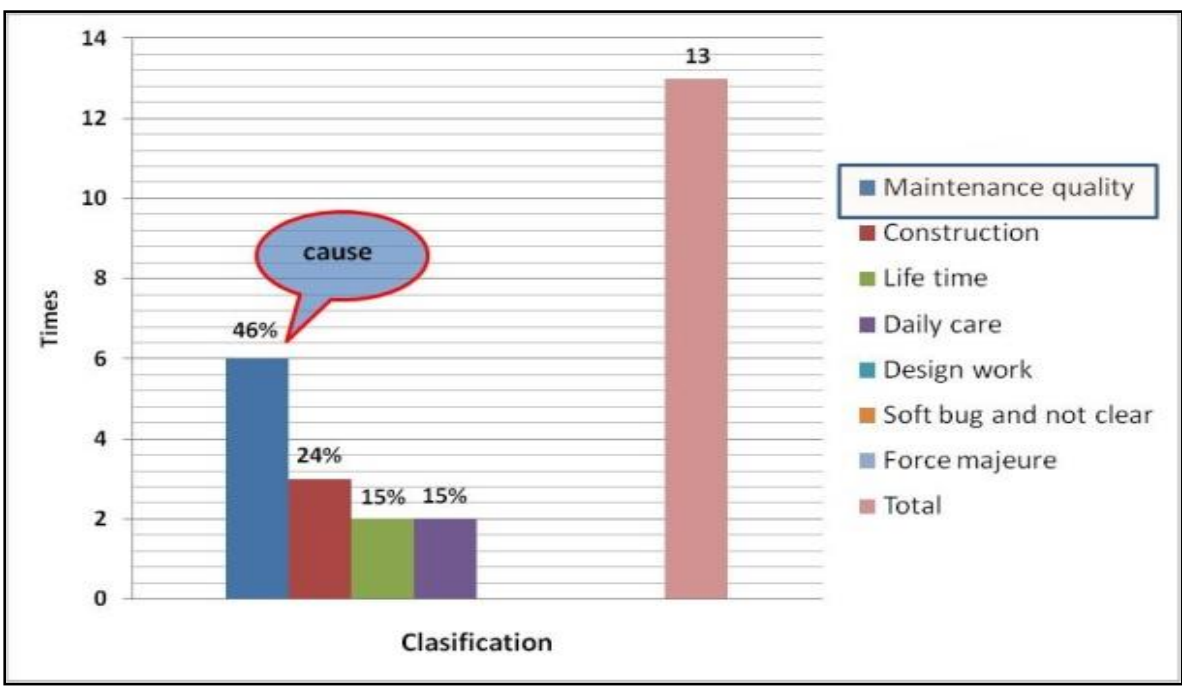

Gambar 6 Grafik Pareto kategori penyebab kerusakan

Dari grafik diatas menunjukkan bahwa kategori Maintenance quality menjadi factor dominan dalam kontribusi losses pada tahun 2010 yaitu sebesar 46\%. Sehingga diperlukan tindakan perbaikan yang berhubungan dengan kualitas pemeliharaan peralatan.

Analisa kerusakan peralatan tahun 2011.

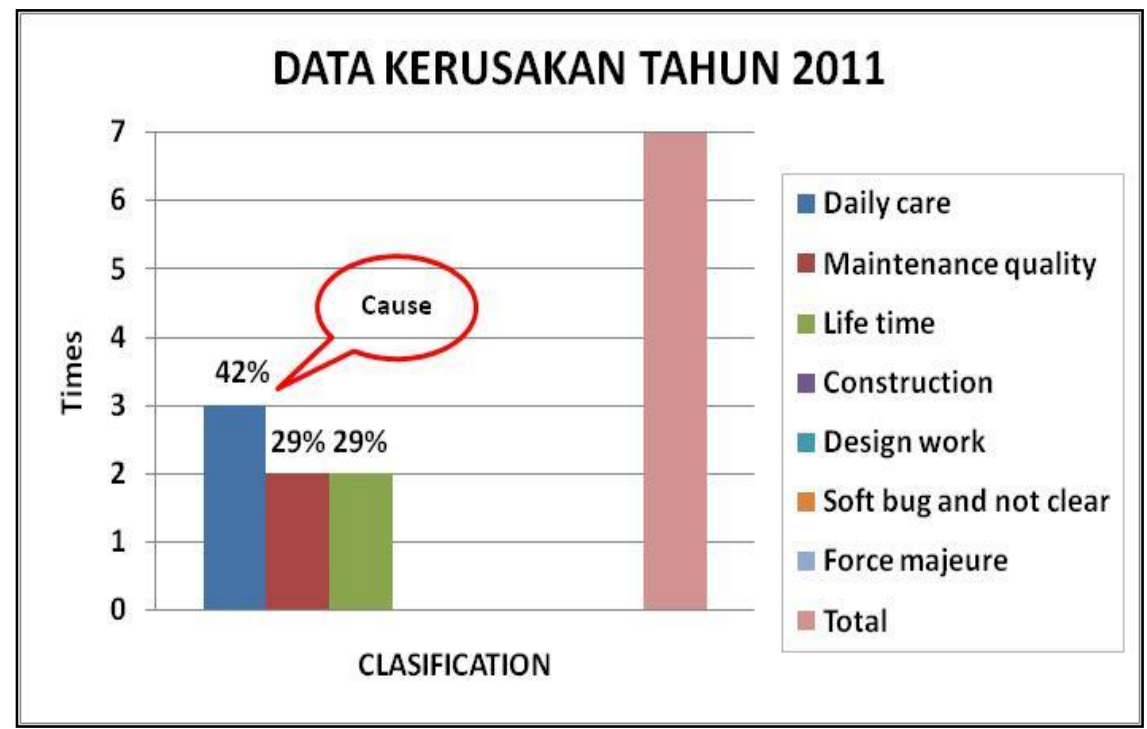

Gambar 7 Grafik Kerusakan peralatan 2012

Sumber : summary trouble report Maintenance (2012).

\section{Temuan perbaikan kerusakan diakibatkan oleh tiga (3) kategori :}

1. Kategori daily care atau kepedulian operator terhadap peralatan masih $42 \%$.

2. Kategori maintenance quality atau qualitas pemeliharaan peralatan $29 \%$.

3. Kategori Life time atau kerusakan karena umur peralatan $29 \%$. 


\section{Implikasi Manajerial}

Secara statistik, kinerja - kinerja peralatan sebelum dan sesudah penerapanMy machine Program memang berbeda, yaitu dengan adanya penerapan My Machine Program, maka kestabilan peralatan produksi akan menjadi lebih baik. Berdasarkan data yang diperoleh, tingkat losses memberikan implikasi dan dampak positif yang paling besar terhadap hasil produksi perusahaan X, melalui strategi My Machine Program dapat mengeliminasi terjadinya losses seperti ditunjukkan dibawah ini

Tabel 11. Sejarah maintenance system PT X.

\begin{tabular}{|c|l|c|c|c|c|}
\hline \multirow{2}{*}{ NO } & \multicolumn{2}{|c|}{ SISTEM PEMELIHARAAN } & \multicolumn{4}{c|}{ TAHUN } \\
\cline { 4 - 6 } & & $\mathbf{2 0 1 0}$ & $\mathbf{2 0 1 1}$ & $\mathbf{2 0 1 2}$ & $\mathbf{2 0 1 3}$ \\
\hline 1 & SISTEM KONVENSIONAL & & & & \\
\hline 2 & TOTAL PRODUCTIVE MAINTENANCE : & & & & \\
\hline & MY MACHINE PROGRAM & & & & \\
\hline 3 & EVALUASI MY MACHINE PROGRAM & & & & \\
\hline 4 & IMPROVEMENT MY MACHINE PROGRAM & & & & \\
\hline & & & & & \\
\hline
\end{tabular}

Dari mulai dijalankan My Machin Program tahun 2011 menunjukkan hasil penurunan losses, dan untuk tahun 2012 dilanjutkan program tersebut .

Tabel 12. Penurunan losses.

\begin{tabular}{|l|c|c|c|}
\hline \multicolumn{1}{|c|}{ Tahun } & Target KPI (min) & Pencapaian (min) & Status \\
\hline 2010 & 870 & $\mathbf{1 6 4 9}$ & Tidak tercapai \\
\hline 2011 & 429 & 259 & Tercapai \\
\hline 2012 & 104 & 35 & Tercapai \\
\hline 2013 & 30 & 0 & Tercapai \\
\hline
\end{tabular}

\section{KESIMPULAN DAN SARAN}

Penelitian ini bertujuan untuk menganalisis perbedaan kestabilan proses produksi sebelum dan sesudah penerapan strategi My Machine Program pada sebuah perusahaan manufaktur kaca lembaran di PT X, dalam hal ini khusus pada proses peleburan bahan baku atau furnace area, untuk periode 2010 - 2013. Dari hasil penelitian yang telah dilakukan .dan telah dianalisa, secara umum dapat disimpulkan bahwa terjadi perubahan yang signifikan dari kestabilan peralatan produksi sebelum diterapkan strategi My Machine Program dengan sesudah diterapkan strategi My Machine Program. Dalam jangka waktu 2 tahun sejak diterapkan My Machine Program, kestabilan operasi peralatan terbukti membaik.

Dalam hal ini ditunjukkan dengan penurunan jumlah kerusakan dan penurunan jumlah losses dari tahun ke tahun. 


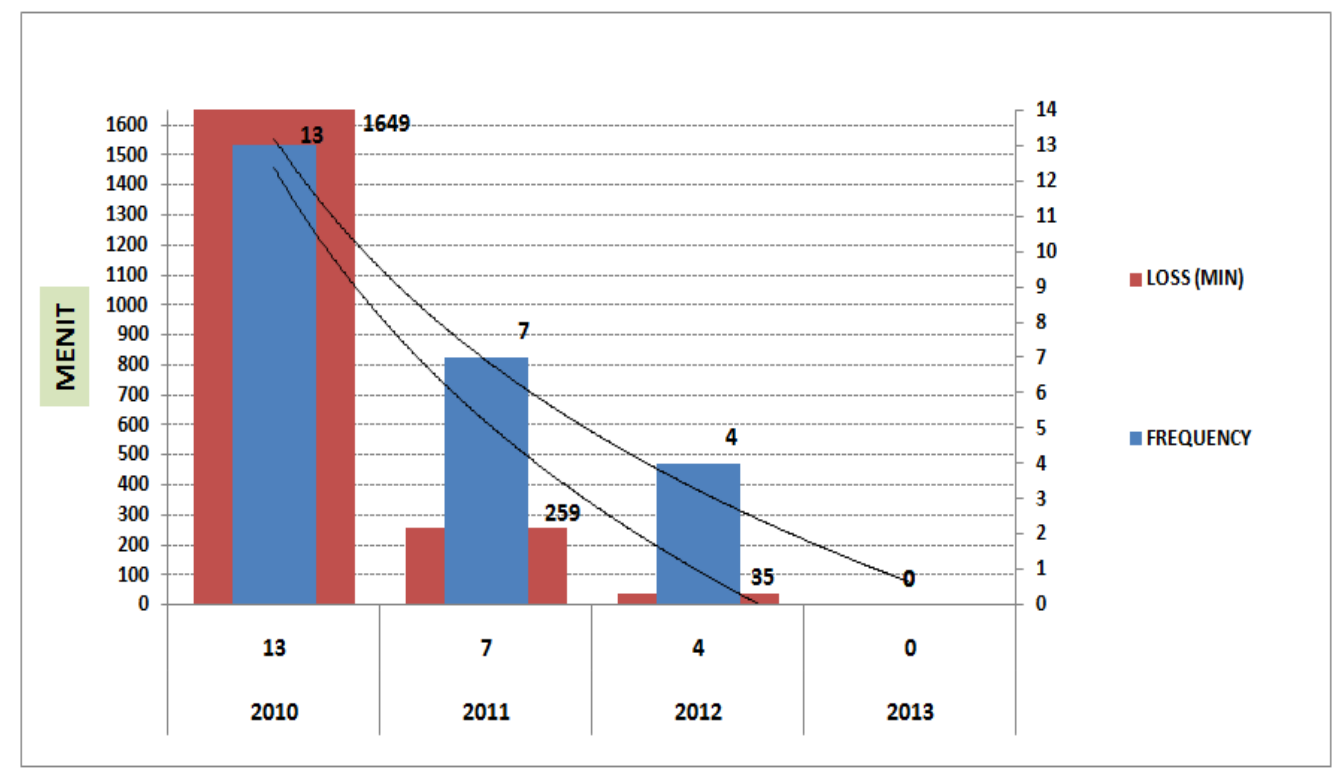

Grafik 7. Jumlah kerusakan

Secara umum dengan penerapan strategi My Machine Program yang konsisten dan benar,maka semua kinerja produksi, secara statistik dan didukung oleh hasil kuesioner yang diberikan kepada operator, dapat menunjukkan hasil yang lebih baik dibandingkan dengan yang belum menerapkan strategi My Machine Program. Dengan demikian penelitian ini bisa menjawab tujuan awalnya adalah peningkatan kestabilan dari operasi peralatan setelah penerapan $M y$ Machine Program dan adanya peningkatan kemampuan karyawan.

\section{DAFTAR PUSTAKA}

Ahmed,Shamsudin., Hj.Hassan,Masjuki., and Toha,Zahari., 2004, "State of implementation of TPM in SMIs: a survey study in Malaysia", Journal of Quality in Maintanance Engineering,Vol.10,pp.93-106.

Dale, B.G., 1999, Managing Quality,3rd ed., Blackwell Publishers Ltd, Oxford.

Davis, R., 1996," Making TPM a part of factory life"' Works Management,Vol.49, part 7,pp.1617.

Dunn,R.L., 1990, “Maintanance of Continuous Processes”, Plant Engineering 44,No.15: 70-76.

E.Rizzo, Kenneth.,1999," Total productive maintenance: A primer”, Package Printing and Converting,pg.26.Gaspersz, Vincent,2001, Total Quality Management, Gramedia, Jakarta.

Ireland, F.and Dale,B.G., 2001, "A study of total productive maintanance implementation", Journal of Quality in Maintanance Engineering, Vol 7,pp.183-191

Nakajima, S., 1986, "TPM - a challenge to the improvement of productivity by small group activities", Maintenance management International, Edition No.6, pp.73 -83.

Nakajima, S., 1988, Introduction to Total Productive Maintenance, Productivity Press, Cambridge, MA.

Nakajima, S., 1989, “ TPM Development Programme: Implementing Total Productive Maintenance, Productivity Press, Cambridge, MA.

Willmott, H. (1994), "Business process re-engineering and human resource

management”, Personnel Review, Vol. 23 No. 3, pp. 34-46. 